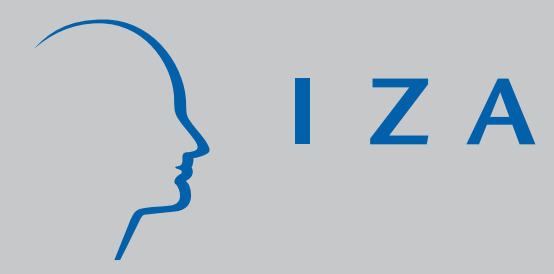

IZADP No. 1626

The Correlates of Work in a Post-AFDC World:

The Results from a Longitudinal

State-Level Analysis

Dan Lewis

Spyros Konstantopoulos

LisaAltenbernd

J une 2005 


\title{
The Correlates of Work in a Post-AFDC World: The Results from a Longitudinal State-Level Analysis
}

\author{
Dan Lewis \\ Northwestern University \\ Spyros Konstantopoulos \\ Northwestern University \\ and IZA Bonn \\ Lisa Altenbernd \\ Northwestern University
}

Discussion Paper No. 1626

June 2005

IZA

P.O. Box 7240

53072 Bonn

Germany

Phone: +49-228-3894-0

Fax: +49-228-3894-180

Email: iza@iza.org

\begin{abstract}
Any opinions expressed here are those of the author(s) and not those of the institute. Research disseminated by IZA may include views on policy, but the institute itself takes no institutional policy positions.

The Institute for the Study of Labor (IZA) in Bonn is a local and virtual international research center and a place of communication between science, politics and business. IZA is an independent nonprofit company supported by Deutsche Post World Net. The center is associated with the University of Bonn and offers a stimulating research environment through its research networks, research support, and visitors and doctoral programs. IZA engages in (i) original and internationally competitive research in all fields of labor economics, (ii) development of policy concepts, and (iii) dissemination of research results and concepts to the interested public.
\end{abstract}

IZA Discussion Papers often represent preliminary work and are circulated to encourage discussion. Citation of such a paper should account for its provisional character. A revised version may be available directly from the author. 


\section{ABSTRACT}

\section{The Correlates of Work in a Post-AFDC World: The Results from a Longitudinal State-Level Analysis}

Much of the research that has followed welfare reform and new policies such as the Temporary Assistance for Needy Families (TANF) has focused on identifying the variations in how different states have put the new policy into practice. Less is known however, about how this new policy affects the ability of recipients to earn a living through work. We use panel data from the state of Illinois and examine what explains labor force participation and performance among current and recent TANF recipients. We use both cross-sectional and longitudinal methods to analyze our data. Our results indicate that human capital factors such as education, job skills, and health are important determinants of labor market participation and performance. In addition, we find that long term welfare recipients are equally likely to participate and perform well in the labor market as shorter term welfare recipients. Finally, government housing subsidy appeared to have a positive effect on labor force participation and performance.

JEL Classification: $\quad$ I38, J20, J24, J30

Keywords: welfare, employment, earnings

Corresponding author:

Spyros Konstantopoulos

School of Education and Social Policy

Northwestern University

2120 Campus Drive

Evanston, IL 60208

USA

Email: spyros@northwestern.edu 


\section{Introduction}

Most modern social policy is made looking backward: A program comes under criticism and review. Reformers look to create an alternative to the discredited approach. The 1996 welfare reform is such a policy. The Personal Responsibility and Work Opportunity Reconciliation Act (PRWORA) was designed to create an alternative to Aid to Families with Dependent Children (AFDC), a policy that had, in the eyes of reform advocates, consigned poor mothers to a world of dependency and pathology. Advocates of reform looked at AFDC and theorized that dependency created by the welfare system trapped people and kept them poor (Murray, 1984; Mead, 1986, Ellwood, 1988). They saw long-term welfare receipt as detrimental and suggested that long term receipt of welfare limited labor force participation. To remove the damage that had been done by AFDC, those on welfare would be forced to move into the labor market; a life of welfare dependency was being denied them. Recipients both potential and real would make more money by working and become productive members of society. Indeed, if AFDC created dependency among long-term recipients, removing the program should allow for the characteristics of the recipient rather than the welfare program to determine labor force participation. A new policy, Temporary Assistance for Needy Families (TANF), makes dependency impossible by placing severe limitations on the receipt of government benefits and should trigger labor force participation based on the characteristics of the person and the labor market. Long-term dependence on welfare should limit the ability of recipients to achieve self-sufficiency through work.

To the surprise of many, welfare reform was a clear success on one dimension; caseloads plummeted. Welfare receipt is much less prevalent today than it was in 1996. Nationally, TANF caseloads declined 54 percent between 1996 and 2003 - from 4.1 million families to slightly more than 2 million families (USDHHS, 2003a). The proponents of the reform believed that the labor market was the alternative to state support.

Yet, in much of the research that followed the change in the welfare law, questions about how the reform would affect the ability of recipients to earn a living through work were still shaped by the legacy 
of AFDC. The main focus of research was to identify variations in how states implemented the law. The new law created a set of options for the poor that made the problems of AFDC impossible; long term dependency is no longer a problem if there is no entitlement to a federal program and eligibility for the new program is time limited. Under these circumstances, a profound reduction in TANF caseloads is inevitable. The legacy of AFDC was to think about work as a function of welfare dependency. Indeed, the 1996 reform was premised on the notion that if you make welfare dependency difficult you will make work likely. Much of the research that followed the reform aimed to assess whether the new incentive system reduced the rolls and increased the likelihood of employment. Since the theory that provided the logic of the reform linked dependency to unemployment this focus seems reasonable and we will pursue that same agenda to some extent. But if the new reform makes dependency impossible because of time limits and work requirements then this new policy environment will make factors other than welfare receipt germane to labor force participation. Indeed like many other reforms of the last generation the policy highlights the importance of individual characteristics since in the absence of strong governmental programs those endogenous characteristics should predict labor force participation.

The impact of welfare reform on labor force participation and earnings for those who receive benefits in the post-AFDC world a nuanced question. Using panel data collected in Illinois, this paper looks forward, asking what factors explain participation and performance in the labor market among welfare recipients after the reforms were implemented? If reform advocates diagnosed the problem correctly and the welfare system was holding people back, then those recipients with more "human capital" will have an advantage: they have more characteristics that employers seek and will participate more in the labor force. Those with less human capital will participate less. That is, we expect to see those with longer welfare receipt participate less in the formal labor market. The irony of welfare reform may be that in order to improve the life chances of those with more human capital, those with fewer skills and resources will be left to rely on the kindness of family members and charity, hardly a compassionate outcome for the latter group. Our research design which focuses on change over time in employment and 
earnings amongst a state sample of welfare recipients allows us to see what the impact is of the welfare reform on labor force participation.

\section{Review of Relevant Literature}

A substantial body of research looked at the effects of AFDC on work effort and consistently found that higher benefits discouraged work (see Moffitt, 1992). Blank (1997) concludes that the AFDC system did serve as a disincentive to work, although the magnitude of the effect on work was not large. Blank (1997) argues that there is little evidence that long-term welfare recipients lose all motivation to work. Many long-term AFDC recipients cycled on and off welfare for work, but returned to AFDC when jobs ended.

Studies of TANF "leavers" comprise the largest body of research on the economic well-being of women who have left welfare after the 1996 reforms. These studies typically use state-level administrative records and/or surveys to examine the well-being of individuals who left welfare. The conclusion from early leavers' studies, many conducted in states where pre-reform waivers were in place, is that welfare reform substantially increased work (Rolston, 1999) and that employment rates among leavers were in the range of 65-75 percent (Brauner \& Loprest, 1999). In a synthesis of 15 post welfare reform studies of leavers, Acs and Loprest (2001) find that about three-quarters of leavers work at some point in the year after exiting TANF and about one-third work in all four quarters after exit. According to administrative records, mean earnings of employed leavers are about $\$ 2,600$ per quarter. A few studies go beyond these measures to examine leavers' progress toward self-sufficiency. These studies indicate that about a quarter of leavers experience material hardship in the year after exit, although working leavers have lower levels of hardship than nonworking leavers.

Cancian et al. (2002) use administrative data to compare labor force participation and earnings before and after leaving welfare among two cohorts of leavers in Wisconsin. They find over half of leavers increased their earnings within one year of exit. While there was more labor force participation among the group that exited after welfare reform was implemented, their earnings were lower. 
There are several major drawbacks of state leavers' studies. First, they tend to be cross-sectional in nature. Panel data are necessary to capture the dynamic nature of the transition from welfare to work in the context of welfare reform. Panel data allow the study of individual trends and the relationship between early and later experiences or behaviors. Second, leavers studies rely on state-level administrative data and/or surveys which do not provide the detail necessary to examine the myriad of influences on labor force participation and earnings.

Another body of literature examines the effects of welfare reform on work force participation and earnings on a national scale. These studies utilize large scale, nationally representative datasets and aim to draw conclusions about the effect of welfare reform that are generalizable to the country as a whole or compare effects in states grouped by different policy attributes. Cancian and Meyer (2000) use data from the NLSY to examine the relationship between work history and economic success in the first five years after exiting welfare. They find that over time wages and hours worked increased and that earnings improved. However, even by the fifth year, only one in four leavers consistently worked full time. In an analysis using SIPP data, Bavier (2001) finds that about two-thirds of welfare leavers worked at some point in the year following exit. Coulton et al. (2003) use SIPP data to examine whether employment levels and the quality of initial jobs obtained by leavers declined over the period 1996-2000 despite the strong economy. Overall, they find a gradual decline in employment and earnings of welfare leavers during 1997 and 1998 followed by an increase by the end of 1999 .

While there are statistical advantages to using large nationally-representative datasets, they miss the complexity and rich detail that are necessary to discover and say something meaningful about welfare policy which, as a result of the 1996 federal law, is made at the state level. It is important to look at welfare reform in context. Detailed state-level panel datasets that include both welfare leavers and stayers provide the most meaningful answers to questions about the effects of welfare reform for current and recent recipients (Danziger et al., 2002).

There is a small body of literature that looks at the effect of welfare reform on economic outcomes of both leavers and stayers using detailed state- and county-level datasets. Johnson (2003) uses 
data from two surveys in Michigan and finds that job skills are critical in determining the ability of former welfare recipients to attain self-sufficiency. Danziger et al. (2002) use two waves of data from a survey in a Michigan county and find that those who leave welfare for work or combine welfare with work are financially better off than those who continue to receive TANF and do not work. Holzer and Stoll in a variety of venues $(2000 ; 2001 \mathrm{a} ; 2001 \mathrm{~b})$ focus on the interface between employers and welfare recipients in the labor market. They point out the importance of the business cycle in the employment patterns of ex-recipients. Kling and his colleagues (2004) examine the Moving to Opportunity (MTO) randomized experiment and find little impact of the experiment on adult employment patterns. Allard and Danziger (2003) look at the proximity of jobs to the residences of welfare recipients and find an effect of proximity on a higher probability of leaving welfare and working.

While the studies discussed above utilize different models for predicting labor force participation and earnings, there are some common findings. All studies find that human capital factors are positively associated with labor force participation and earnings. Consistently, the presence of young children is found to have a negative association with work (Cancian \& Meyer, 2000; Cancian et al., 2002; Coulton et al., 2003 ) and several studies find positive effects of cohabitation (Danziger et al., 2002; Corcoran , Heflin \& Siefert, 2003). The few studies that include welfare use in models predicting employment and earnings find results contrary to expectations. Danziger et al. (2002) find a positive association between time on welfare and income and Cancian et al. (2002) find a positive association between welfare use and employment. Cancian and colleagues a negative association between welfare use and earnings. These contradictory findings between welfare use and labor force participation and earnings after welfare reform clearly highlight the need for further research.

\section{Welfare Reform in Illinois}

An examination of welfare reform in Illinois is particularly instructive for several reasons. First, in August 1996 the state's AFDC caseload was the fourth largest in the nation (USDHHS, 2000). Second, Illinois welfare reform policies are considered to be moderate in comparison to other states, providing an excellent example of the "middle of the road" approach to reform with a mixture of work 
incentives and penalties for non-cooperation (Lewis et al., 2002). Third, unemployment in Illinois was on par with the national average during the mid- and late-1990s. Thus, the Illinois experience is reasonably representative of a number of states with moderate or incentive-based welfare reform policies and favorable economic climates.

Lewis et al. (2004) report descriptive findings on the effect of welfare reform in Illinois. Mirroring national trends, AFDC/TANF use declined sharply in Illinois starting in the mid 1990s, from a high of 208,646 AFDC cases in 1994 to 11,225 TANF cases in 2003. The large declines in TANF receipt were not matched by comparable increases in work; consistently about half of current/recent TANF recipients work for pay at a point in time across four study waves. That is, work does not appear to be increasing over time. This paper seeks to go beyond point in time estimates of work to examine the length of time spent in the labor market and earnings from that participation. Moreover, while descriptive analyses are useful, they do not address the correlates of work force participation and earnings. In the present study, we take up that challenge by utilizing multivariate methods. This research is among the first to examine work force participation and earnings using state-level panel data collected after the implementation of welfare reform that includes detailed information on both welfare leavers and welfare stayers.

\section{Research Questions}

The goal of this paper is to examine what welfare reform means for the labor market participation and earnings of those who receive temporary benefits under the new welfare system. Specifically, we address the following questions:

1. To what extent do current and recent TANF recipients participate in the formal labor market? Is labor market participation increasing over time?

2. What are factors that predict labor market participation among a sample of current and recent TANF recipients?

3. How much do current and recent TANF recipients earn in the formal labor market, on average? Are earnings increasing over time? 
4. What are factors that predict labor market performance among a sample of current and recent TANF recipients?

We hypothesize that human capital and individual-level variables will predict who is in the labor market and their performance as measured by earnings. We expect higher levels of human capital to be associated with more participation in the labor force and higher earnings. We also hypothesize that longterm receipt of welfare will limit labor market participation and earnings.

\section{Method}

\section{Sample and Procedures}

The Illinois Families Study (IFS) is a six-year panel study of families who were receiving TANF during September, October, or November 1998. A stratified random sample of families was selected along two geographic regions: Cook County (which includes Chicago) and eight counties in "downstate" Illinois. Together, these nine counties represented 75 percent of the state TANF caseload in 1998. The study oversampled families from the eight downstate counties in order to ensure sufficient sample sizes within smaller counties and to enable comparison between urban and more rural regions in the state.

The core of the IFS is data from annual survey interviews and individual-level data from state administrative systems. Survey and administrative data were linked using a probabilistic matching algorithm that relies on multiple pieces of identifying information such as name, birth date, gender, race/ethnicity, county of residence and social security number (Jaro, 1985; Newcombe, 1988; Jaro, 1989; Goerge \& Lee, 2001). Interviews were conducted in late $1999-2000,2001,2002$ and 2003. The response rate was 72 percent for Wave $1(\mathrm{~N}=1,363), 87$ percent for Wave $2(\mathrm{~N}=1,183), 91$ percent for Wave $3(\mathrm{~N}=1,072)$ and 91 percent for Wave $4(\mathrm{~N}=967)$. Respondents' addresses at each wave were geocoded and linked to the 2000 Census.

The sample was selected more than a year after welfare reforms were implemented in Illinois. Whereas all respondents received TANF in the fall of 1998, about half had left welfare by the Wave 1 interview (approximately 18 months later); almost 90 percent of respondents had left welfare by the Wave 4 interview (Lewis et al., 2004). 
An analysis weight was developed to adjust for the non-proportional nature of the sample and the differences in non-response rates across various known demographic characteristics of the population. The results reported in the present study are based on an adjusted sample using the analysis weights.

The IFS data have several advantages. First, because the data are from a random sample of welfare recipients with high response rates, the analysis is reasonably representative of the post-TANF welfare population in Illinois. Second, the dataset allows us to control for a particularly rich set of individual characteristics which to help explain labor market participation and performance. Third, our use of Unemployment Insurance (UI) records for data on earnings addresses potential bias in our estimates due to underreporting; self-report data on income from work among welfare populations is often underreported (Edin \& Lein, 1997). In addition, UI data provide a measure of official, "above the table" work, the kind of work that is the cornerstone of welfare reform. Finally, the dataset used here provides longitudinal data for four points in time, allowing us to examine the dynamic nature of work force participation and performance among the current and recent welfare population.

\section{Limitations of the Present Study}

Even though our data are rich, there are some limitations. First, given our data it is difficult to separate the influence of TANF policy from other policy and economic changes that occurred during the period. It is likely that the effects of a strong economy moved some TANF recipients into the work force more quickly than they might have under less favorable conditions. Second, access to child care subsidies and health insurance may have affected labor force participation and earnings, but these variables were not available in our data. Third, detailed data about county or local effects or job accessibility and labor market opportunities were not available. Fourth, it is important to note a tradeoff when using UI data to measure work is that they do not capture "under the table" or informal work, which is well-documented among low-income populations (Edin \& Lein, 1997). Thus, UI data may underestimate total earnings from the full range of work activities. Another final limitation is that this study may suffer from cohort effects. Specifically our study does not include younger or more recent recipients who may have different characteristics than those recipients in our sample. 


\section{Variables of Interest}

Dependent variables. The dependent variables in these analyses are labor force participation and earnings. The labor force participation variable is a measure of employment. At each wave individuals were asked to provide an estimate of how many months they worked at least 10 hours per week during the last year or since their last interview. We constructed a variable that represents the proportion of months individuals worked at each time point by dividing the number of months they worked within a period of time by the number of total months within that period. In other words, we use a relative measure instead of an absolute measure of labor force participation. We also conducted sensitivity analyses using the absolute measure (number of months a person worked) as the dependent variable and our estimates were comparable to those produced from analyses using the relative measure.

We use administrative data from the UI system to measure earnings. Pre-tax earnings in the four quarters prior to the beginning of each survey wave were summed to yield a measure of annual income from work. We transformed earnings using the natural logarithm and conducted all earnings analyses across all waves regressing log earnings on the set of explanatory variables.

Independent variables. The Appendix lists the independent variables, their measures, and coding for analysis. Our set of explanatory variables is grouped into five major categories. The first category includes indices of human capital. These consist of educational attainment presence of job related skills, and health status. As human capital theory posits, education enhances labor market participation and productivity (Becker, 1964). Investments in human capital are expected to yield sizable economic and social rates of return. Therefore, we hypothesize that individuals who completed high school are more likely to be in the labor force for longer periods of time and earn more on average than individuals with less education. In the same vein we expect that individuals with job skills have a higher probability of being in the labor force for longer periods of time or earning more money. The relationship between health status and employment among the recent welfare population is well established (Danziger et al., 2000; Polit, London, and Martinez, 2001). We expect an inverse relationship between poor health and labor force participation and earnings. 
The second category of explanatory variables is non-wage income. This category includes formal and informal child support, financial support for living expenses from a marital or nonmarital partner and government rent subsidy. It is not obvious how these variables are related to duration in labor force participation. For example, high levels of support may decrease the likelihood of joining the labor market for longer periods of time. On the other hand, such variables may relieve the stress of making ends meet and function as an incentive that will increase the likelihood of longer labor market participation.

Neighborhood characteristics including average income and percent unemployment in the Census tract comprise the third category of explanatory variables. We expect a positive relationship between average neighborhood income and labor force participation or earnings. We hypothesize an inverse relationship between unemployment and labor force participation or earnings.

The fourth group of explanatory variables includes demographic characteristics such as race/ethnicity, age, marital status, and having at least one child under the age of three. Race differences in labor market participation and performance between minority and majority groups are well documented in the social science literature (Smith and Welch, 1986; O’Neill, 1990). We expect that African Americans will have less labor force participation and earnings on average than whites or Hispanics. Labor force participation and earnings typically increase with age at a decreasing rate. Thus, we include in our models the linear and the quadratic term for age. We expect married individuals to have a higher probability of working and potentially higher earnings (Korenman and Neumark, 1991). In contrast, we expect that caregivers with young children will be less likely to be in the labor force and earn less than those with older children.

The fifth group of explanatory variables includes controls such as time on welfare, family hardship, housing expenses, informal work status and region. We expect longer-term welfare receipt to limit labor force participation and earnings. We expect housing costs to be positively related to our outcomes; higher levels of housing expenses may be associated with higher levels of labor force participation and earnings. In contrast, we expect that individuals who work informally and those who 
reside in Cook County will have a lower likelihood of being in the labor force and will have lower levels of earnings.

\section{Analytic Approach}

\section{Cross-Sectional Analysis}

It is possible that our dependent variables, proportion of months in the labor force and earnings, are limited in their range. For example, earnings may only be available for individuals for whom actual earnings exceed reservation earnings, since some individuals choose not to work (Kennedy, 1998). In this case the earnings of the individuals who are not in the work force are not observed. This implies that our dependent variables may be censored and hence, the typical ordinary least squares estimates may be biased even assuming large samples. Specifically, it is plausible that values of our dependent variables at or below zero are censored. Hence, our model examines left censored data, since the individuals who do not work are left censored at zero.

To account for this potential sample selection bias we use a Tobit model which is a straightforward extension of the probit and a natural extension of a linear regression (Greene, 1997; Johnston, \& DiNardo, 1998; Kennedy, 1998). The Tobit model is a simple one-step way to adjust for sample selection employing maximum likelihood estimation. It is appropriate for left-censored data with normally distributed errors (see Kennedy, 1998). The Tobit model provides estimates of the parameters of the distribution of the uncensored data and hence adjusts for selection bias. For each wave we use Tobit models and regress our dependent variables (proportion of months in the work force and earnings) separately onto the sets of explanatory variables described above.

\section{Longitudinal Analysis}

Since our data are naturally longitudinal we are also interested in examining individual change over time. The longitudinal analyses address research questions one and three about changes in employment and earnings over the four-wave period. Specifically, we are interested in determining whether labor force participation and earnings change over time. For example, it is possible that 
individuals may be employed for longer periods over time. Similarly, their earnings may get higher over time. Note that higher earnings do not necessarily indicate higher hourly wages. This may simply be a result of working more hours per week for longer periods of time. Since we have panel data for four waves (or time points) we use repeated measures models with nested structure in order to include all information available from all four waves and determine changes in labor force participation or earnings over time. Such analyses are more likely to produce statistical tests with higher statistical power (since the data are almost four times as large), and thus, there is a higher probability of detecting significant associations of interest. Since our data provide information for the same individuals over a four-year period it is likely that our time points are dependent. Specifically, our data are nested since over time there are multiple observations for each individual, and these observations are clustered within individuals. In our case, individuals may have up to four observations over time.

Therefore, an appropriate statistical model for analyzing our nested data should take into account the dependency of the multiple observations within individuals. This is essential for the computation of the standard errors of the estimates. In addition, since we are interested in whether individual change varies across individuals our statistical model should allow for random effects of change over time. Hence, we employ two level hierarchical linear models that satisfy both conditions; that is, provide robust standard errors, and allow for random effects of change over time (see Raudenbush, \& Bryk, 2002).

At the first level we use a temporal change model where an individual's development is portrayed by a "growth" trajectory that is unique for each individual (see Raudenbush \& Bryk, 2002). The first level is hence a within-person model with repeated observations for each person over time. At the second level the growth over time becomes an outcome variable which is regressed on individual characteristics. The second level model is therefore a between-person model.

Specifically, at the first level we employ a linear change model. If we assume that there are $t$ repeated observations over time for person $i$, then the first level model is described as

$$
Y_{t i}=\beta_{0 i}+\beta_{1 i} \text { Wave }_{t i}+\varepsilon_{t i}
$$


where $Y_{t i}$ represents labor force participation or earnings for time $t$ (Wave 1 for example) for individual $i$; $\beta_{0 i}$ represents the initial status of labor force participation or earnings in Wave $1 ; \beta_{1 i}$ represents the temporal change in labor force participation or earnings from Wave 1 to Wave 4; and $\varepsilon_{t i}$ is a wave- and person-specific residual.

At the second level we predict temporal change using our wave 1 predictors and thus our model is described as

$$
\beta_{1 i}=\gamma_{10}+\sum_{q=1}^{Q} \gamma_{1 q} X_{q i}+u_{1 i},
$$

where $X_{q i}$ represent q person-specific predictors (e.g., race); $\gamma_{1 q}$ are the regression coefficients indicating the associations between temporal change and individuals' characteristics respectively; $\gamma_{10}$ represents the average change over time; and $u_{1 i}$ is a person-specific residual, the variance of which indicates differences in change over time across individuals.

\section{Results and Discussion}

\section{Descriptive Statistics}

Table 1 summarizes the descriptive statistics for the variables of interest across all four waves. The individuals in our sample participate in the labor force approximately half a year in each wave. This is consistent across waves and indicates no temporal change in labor force participation over time. On average, across all waves, somewhat more than $30 \%$ of the people in our sample reported no employment. In the first two waves about one fourth of the individuals in our sample reported working 12 or more months during the period in between interviews (this percentage was reduced to about $10 \%$ for Waves 3 and 4). The average earnings across waves range from about $\$ 5,000$ to $\$ 7,000$. Sixty to seventy percent in our sample have a high school degree. About seventy percent of respondents have job related skills. Nearly one out of four individuals is in poor health or has a chronic health problem. About fifty percent of 
respondents receive formal or informal child support, while only twenty to thirty percent receive financial support for living expenses from a spouse or partner across all four waves. Overall, respondents live in distressed neighborhoods; average household income is about $\$ 30,000$ and there is high unemployment (17\%). The majority of our sample (78\%) is African American, twelve percent are Hispanic, and about seven percent are white. This racial/ethnic breakdown is consistent with TANF caseloads overall in Illinois (USDHHS, 2003b). On average, our sample is in their early thirties and has two to three children. The majority of individuals in our sample are not married or cohabitating. Across all waves $11 \%$ of our sample are married and 7\% are cohabitating. As of the sampling period, individuals had spent about 6.5 years on welfare on average. Time on welfare ranged from one to 116 months (9.67 years). Nearly $25 \%$ had been on welfare up to four years, and another $30 \%$ had been on welfare nine or more years. About one quarter of respondents worked informally at each wave. The overwhelming majority of our sample (90\%) resides in Cook County, which includes mainly Chicago residents.

Table 1 about here

Table 2 summarizes work status and welfare use for all four waves. The proportion of people who were on welfare only (not working) at the time of the survey decreased dramatically over time from $32 \%$ in Wave 1 to 9\% in Wave four. A larger proportion of people (nearly 15\%) reported working only in Waves 2, 3, and 4 than in Wave 1 . This is encouraging since a primary goal of the 1996 reforms was to move recipients from welfare to work. It is noteworthy that the proportion of people who do not work and are not on welfare more than doubled from Wave 1 to 4 . This indicates that people who leave welfare do not necessarily seek employment; they instead find means of support besides welfare or work. Also worth noting is the decreasing proportion of the sample who combine work and welfare, from $21 \%$ in Wave 1 to $2 \%$ in Wave 4 . Illinois' welfare reform law provides a mechanism for individuals to work and 
receive welfare without facing time limits. Given this policy, it is surprising that almost none of the IFS sample were combining work and welfare by Wave 4.

Table 2 about here

\section{Results of Cross-Sectional Analyses}

The results obtained from the cross-sectional analyses are reported in Tables 3 and 4 . It is important to note before proceeding with the interpretation of estimates that the predictors used in our models are not necessarily causally related to employment and earnings. Since overall there is no proper temporal ordering between the predictors and the outcomes, our results mainly indicate correlational associations. The multivariate associations between our set of explanatory variables and duration in labor force participation are reported in Table 3 for all waves of the study. As expected, human capital factors are predictive of time in the formal labor market. Education is consistently a positive and significant predictor of duration in labor force participation across all four waves net of the effects of other predictors. Specifically, individuals with a high school degree are more likely to be in the labor force for longer periods of time than individuals with lower levels of education. Job skills are a positive and significant predictor of duration in labor force participation for Waves 1 and 4 when all other predictors are held constant. The multivariate association between health status and duration in labor force participation is not surprising. Poor health is negatively and consistently associated with duration in labor force participation in Waves 1, 2 and 4. All indices of human capital function as expected.

Table 3 about here 
The variance components of the initial status at wave 1 and the temporal change for waves 1 to 4 were significantly different from zero for both employment and earnings. This suggests that the individuals in our sample varied significantly in labor force participation and performance not only in the beginning of the study, but also for the whole duration of the study. This result highlights the importance of individual differences in labor market outcomes.

Receiving a housing subsidy is a positive and significant predictor of duration in labor force participation across all waves when other predictors are held fixed. This is an important finding since it suggests that providing support for rent may have a positive effect on labor force behavior. While we are cautious about implying a causal relationship between receiving a government housing subsidy and labor force participation, we think that reverse causation is unlikely. While it may be the case that those who work more are more likely to be self supporting and hence eligible to receive a rent voucher (such as Section 8), our measure of housing subsidy includes all forms of government support for rent, including public housing. It does not seem plausible that residents of public housing work more, so we argue that government support for rent affects labor force participation and not the other way around. Hispanics were significantly more likely to participate in the labor force for longer periods of time than African Americans in Waves 1 and 3, net of the effects of other predictors. As expected, duration in labor force participation increases with age at a decreasing rate. The association between marital status and duration of employment was inconsistent. This may be indicating that our measure of marriage/cohabitation does not accurately capture the types of relationships among our sample. Marital status and cohabitation can be unstable variables, especially in lower income samples. Hence, we argue that there is a lot of interpretive noise in our marital status variable and it is possible that we don't capture the complexity of actual relationships.

In addition, mothers who have at least one child under the age of three are significantly less likely to participate in the labor force for longer periods of time. Being on welfare for nine years or more did not affect labor force participation. This is a surprising finding since one would expect that the longer a person is on welfare the lower the probability of labor force participation. However, we find no 
association. Family hardships decreased the likelihood of labor force participation, while housing expenses increased the likelihood of participating in the work force for longer periods of time. The association between housing expenses and duration of employment is not causal, since higher levels of labor force participation can cause higher housing expenses. Finally, individuals residing in more urban Cook County participate significantly less in the labor force than individuals in more rural counties in Illinois.

Table 4 summarizes the multivariate associations between our sets of explanatory variables and labor force performance (earnings) for all waves. As hypothesized, education is consistently a positive and significant predictor of earnings for Waves 1,2, and 4 net of the effects of other predictors. Individuals with a high school degree earn significantly more than individuals with lower levels of education. As expected job skills, are positively and significantly related to earnings in Waves 2 and 4 . Poor health is negatively and consistently associated with earnings across all waves indicating that individuals in poor health earn significantly less than individuals in good health. As in the models predicting labor force participation, the human capital variables function as hypothesized in predicting earnings.

Table 4 about here

As expected, individuals who live in neighborhoods where average household income is greater than $\$ 40,000$ have significantly higher earnings than individuals who live in poorer neighborhoods in Waves 1 and 2. Race differences are also detected. Individuals in the other race category have on average significantly lower earnings than African Americans across all waves. We find a positive and significant relationship between age and earnings in Waves 1 and 2. Earnings also increase with age at a decreasing rate. In addition, mothers who have at least one young child earn significantly less than other mothers in all Waves. Being on welfare for nine years or more did not affect earnings. This echoes the finding of the 
model predicting labor force participation and is contrary to expectations. We expect that the longer a person is on welfare the lower their employment rates and wage income would be. Family hardships are negatively associated with earnings in Wave 2 and 3, while higher levels of housing expenses are significantly related to higher earnings across all waves. Again, the association between housing expenses and earnings is not causal, since higher levels of earnings can result in higher housing expenses. As expected, individuals who work in the informal labor market have lower earnings from formal employment than others. Regional differences in earnings were not detected indicating that residents of Cook County earn as much as residents in other counties.

\section{Results of Longitudinal Analyses}

The results from our longitudinal analyses are summarized in Table 5. In the longitudinal analyses we used all information available from all four waves. The results in Table 5 indicate the multivariate associations between our predictors in Wave 1 and temporal changes over time in labor force participation and earnings. The estimates for change in employment are reported in column 2 and the estimates for change in earnings are reported in column 4 . The change in duration in labor force participation is positive and significantly different from zero. This indicates that the individuals in our sample worked longer periods over time. This may be due to the fact that more individuals were employed over time (see Table 2). Educational attainment in Wave 1 is positively associated with temporal change in employment over time. This indicates that high school graduates are more likely to participate in the labor force for longer periods of time than others over the course of four years. Health was also a significant predictor of work over time. Healthy individuals worked longer periods over time than less healthy individuals. Housing subsidy at Wave 1 was positively associated with change in duration of employment over time, and in this case there is proper temporal ordering. It is noteworthy that being on welfare nine or more years was not significantly associated with change in duration of employment over time. Housing expenses in Wave 1 was a positive and significant predictor of change in 
duration of employment over time, and the temporal ordering is proper. All other predictors of change in labor force participation were not significant at the 0.05 level.

Column 4 in Table 5 indicates that there is a negative temporal change in earnings over time. This trend however, is not statistically significant according to our longitudinal estimates. Educational attainment in Wave 1 is positively associated with temporal change in earnings over time. This indicates that high school graduates are more likely to earn more than nongraduates over the course of four years. Long term welfare receipt is not significantly associated with change in earnings over time. Receiving welfare for nine or more years does not affect the likelihood of higher earnings over time. Housing expenses was a positive and significant predictor of change in earnings. The remaining predictors were not significantly associated with temporal change in earnings over time.

Table 5 about here

\section{Discussion}

In this study we undertook a thorough analysis to examine labor market outcomes of individuals who were receiving TANF after welfare reform was implemented in Illinois. Specifically, we aimed to determine the most important predictors of labor force participation and earnings. We used a rich, statelevel panel dataset that included information about individual characteristics, community characteristics, and labor force outcomes from survey and administrative sources.

Overall, our findings from the cross-sectional and longitudinal analyses suggest that, net of the effects of other predictors, time on welfare is not associated with labor market outcomes such as participation and earnings. This important finding indicates that long-term welfare use has no significant effect on the likelihood of participating or doing well in the labor market. While this finding is contrary to expectations, it is consistent with findings from studies that use county- and state-level panel data to examine the effect of welfare reform on the economic outcomes of welfare leavers (Cancian et al., 2002; 
Danziger et al., 2002). This finding is also consistent with Blank's (1997) argument that long term AFDC receipt did not destroy motivation to work, since even long term recipients regularly cycled on and off AFDC for employment. For the first time, long term welfare recipients are required to participate in the labor market in whatever job is available. Controlling for human capital factors, the long term receipt of welfare has no independent effect on that participation. This suggests that time on welfare, by itself, does not capture an important quality of the recipient when it comes to labor force participation. If long term recipiency does not affect labor force participation, the welfare reform philosophy may not have been built on a solid foundation, but the result may be fortuitous for our sample. Being on welfare was in and of itself supposed to be a negative. That negative should have, but did not, affect labor force participation. The result for long term recipients now forced to work was negligible, surprising scholars on both the left and right.

In congruence with the human capital theory (Becker, 1983) individuals who have completed high school, have acquired job related skills, and are in good health are more likely to participate and perform well in the labor force. This is an important but not surprising finding suggesting that the labor force participation and earnings for individuals with a similar welfare history, similar age and race, who live in comparable neighborhoods is greatly determined by their human capital status. It is important to note that human capital, education and health in particular, was consistently a significant predictor of labor force participation and earnings even after controlling for a host of potential explanatory variables from both self-report and administrative sources. This finding has important policy implications, suggesting that investments in education and health have long-terms payoffs in employment and earnings.

Within the intellectual framework created by AFDC, it may have appeared that welfare receipt was causing individuals to stay out of the labor market. A world without AFDC reveals that personcentered factors (human capital) become increasingly important in explaining work and earnings. However, the challenge of attaining self-sufficiency does not disappear when AFDC disappears. Rather, personal resources become more visible and it is easier to identify their role in explaining economic effort 
and outcomes. In other words, when barriers to equality such as the old welfare system are removed, individual differences become more visible and important.

A number of other correlates predict labor force participation and earnings among our sample. Our results suggest that receiving a government housing subsidy enhances labor force participation and earnings. This finding has important policy implications, suggesting that providing housing assistance is a way to support work among those transitioning from welfare. Policymakers should be aware that the current efforts to reduce federal housing assistance many have the unintended consequence of reducing work effort. Contrary to expectations, we did not find any consistent significant race differences with respect to labor market outcomes among the three major race/ethnic groups (African Americans, Hispanics, Whites). We find a consistent and negative effect of region on labor force participation. Specifically, individuals residing in more urban Cook County are typically less likely to participate in the labor force for longer periods of time than individuals who live in more rural counties in downstate Illinois. This suggests that there are important regional differences in labor market outcomes that go beyond the economic climate (we control for the unemployment rate), living expenses (we control for the cost of housing), and race. The Chicago - Downstate comparison may very well capture the convergence of the city's heavy reliance on public housing that isolates many welfare recipients in highly stigmatized communities and the extremely segregated nature of its communities. It may also measure indirectly the spatial mismatch between job requirements and welfare recipients' skills. As expected, mothers who have children less than three years of age are less likely to participate and perform well in the labor market than mothers whose children are older. This result may capture the desire of mothers with young children to stay at home or reflect the difficulty in finding affordable, flexible child care.

In general, we find lower earnings in our study than in studies of welfare leavers (Cancian et al., 2002; Acs \& Loprest, 2001). This is not surprising since we also include welfare stayers, whose income from work is likely to be low since they continue to receive TANF, as well as unemployed leavers. An important finding is that there is a significant increase in labor force participation but not in earnings over 
time. A primary goal of welfare reform is to increase self-sufficiency through work; however, it is unlikely that working half the year earning approximately $\$ 6,000$ on average is enough to meet that goal. Although a sizeable portion of individuals derived additional income and nonmonetary resources from other sources, it is unlikely that these are substantial enough to promote or ensure economic security. In fact, at Wave 4 of the survey 95 percent of the IFS sample was living in poverty (Lewis et al., 2004). 


\section{Conclusion}

Welfare reform removed AFDC, a structure that was thought to create dependency and a disincentive to work. Nearly a decade after welfare reform in Illinois, the poor have shifted into the labor market, improving the situations of those with sufficient human capital but leaving many single mothers with young children in a precarious situation. The results from this study show that individuals who start out more advantaged end up realizing their potential, suggesting that the alternative to "welfare as we knew it" is a postmodern world of "survival of the fittest." The labor market will distribute people according to the amount of human capital they possess and the result will be hardship for those that are the least equipped to compete. While few would want to return to the discredited AFDC program, it seems unacceptable to abandon those poor mothers with the least human capital to the exigencies of the market place. 


\section{References}

Acs, Gregory and Pamela J. Loprest. 2001. Initial Synthesis Report of the Findings from ASPE'S "Leavers" Grants. Washington, DC: Urban Institute.

Allard, Scott W. and Sheldon Danziger. 2003. "Proximity and Opportunity: How Residence and Race Affect the Employment of Welfare Recipients." Housing Policy Debate 13(4): 675-700.

Becker, Gary S. 1964. Human Capital. New York: Columbia University Press.

Becker, Gary S. 1983. Human Capital: A Theoretical and Empirical Analysis, with Special Reference to Education. Chicago, IL: University of Chicago Press.

Bavier, Richard. 2001. "Welfare reform data from the Survey of Income and Program Participation." Monthly Labor Review 124(7): 13-24.

Blank, Rebecca M. 1997. It Takes a Nation: A New Agenda for Fighting Poverty. New York: Russell Sage Foundation.

Brauner, Sarah and Pamela J. Loprest. 1999. Where Are They Now? What States' Studies of People Who Left WelfareTell Us. Washington, DC: The Urban Institute, No. A-32.

Cancian, Maria and Daniel R. Meyer. 2000. "Work After Welfare: Women's Work Effort, Occupation, and Economic Well-being." Social Work Research 24(2): 69-86.

Cancian, Maria, Robert H. Haveman, and Barbara Wolfe. 2002. "Before and After TANF: The Economic Well-being of Women Leaving Welfare." Social Service Review December: 603-641.

Connolly, Laura S. 2000. "The Effect of Welfare Reform on the Incomes and Earnings of Low-income Families: Evidence from the Current Population Survey." Presented at the Rural Dimensions of Welfare Reform: A Research Conference on Poverty, Welfare, and Food Assistance, Joint Center for Poverty Research, May 4-5, Washington, DC.

Corcoran, Mary, Colleen M. Heflin, and Kristin Siefert. 2003. "Work Trajectories, Income Changes and Food Insufficiency in the Welfare Population." Available at http://www.fordschool.umich.edu/poverty/publications.htm.

Coulton, Claudia, Younghee Lim, Thomas Cook, and Nina Lalich. 2003. "Did Welfare Leavers' Employment Levels and Job Characteristics Change During TANF Implementation?: An Analysis Using SIPP 1996-2000.” Cleveland, OH: Center on Urban Poverty and Social Change, Case Western Reserve University.

Danziger, Sandra K., Mary Corcoran, Sheldon Danziger, Colleen M. Heflin, Ariel Kalil, Judith Levine, Daniel Rosen, Kristin S. Seefeldt, Kristine Siefert, and Richard M. Tolman. 2000. "Barriers to the Employment of Welfare Recipients." Pp. 239-272 in Robert Cherry and William M. Rodgers III eds., Prosperity for All? The Economic Boom and African Americans. New York: Russell Sage Foundation.

Danziger, Sheldon, Colleen M. Heflin, Mary E. Corcoran, Elizabeth Oltmans, and Hui-Chen Wang. 2002. "Does it Pay to Move from Welfare to Work?" Ann Arbor, MI: Poverty Research and Training Center, University of Michigan. 
Edin, Kathryn and Laura Lein. 1997. Making Ends Meet: How Single Mothers Survive Welfare and Low-Wage Work. New York: Russell Sage Foundation.

Ellwood, David T. 1988. Poor Support. New York: Basic Books.

Goerge, Robert and Bong Joo Lee. 2001. "Matching and Cleaning Administrative Data." In C.F. Citro, Robert Moffitt, and M. Ver Ploeg eds., Data Collection and Research Issues for Studies of Welfare Populations: Panel on Data and Methods for Measuring the Effects of Changes in Social Welfare Programs. Washington, D.C.: National Academy Press.

Greene, William, H. 1997. Econometric Analysis. Upper Saddle River, NJ: Prentice Hall.

Holzer, Harry. 1996. What Employers Want: Job Prospects for Less-educated Workers. New York: Russell Sage Foundation.

Holzer, Harry J. and Michael A. Stoll. 2000. "Employer Demand for Welfare Recipients by Race.” Evanston, IL and Chicago, IL: Joint Center for Poverty Research.

Holzer, Harry J. and Michael A. Stoll. 2001a. "Employers and Welfare Recipients: The Effects of Welfare Reform in the Workplace." San Francisco, CA: Public Policy Institute of California.

Holzer, Harry J. and Michael A. Stoll. 2001b. "Meeting the Demand: Hiring Patterns of Welfare Recipients in Four Metropolitan Areas." Washington, DC: The Brookings Institution.

Jaro, Matthew A. 1985. "Current Record Linkage Research.” Proceedings of the Statistical Computing Section, American Statistical Association: 140-43.

Jaro, Matthew A. 1989. "Advances in Record-linkage Methodology as Applied to Matching the 1985 Census of Tampa, Florida." Journal of the American Statistical Association 84(406): 414-420.

Johnston, Jack and John DiNardo. 1998. Econometric Methods. New York: McGraw-Hill.

Kennedy, Peter. 1998. A Guide to Econometrics. Cambridge, MA: MIT Press.

Kling, Jeffrey R., Jeffrey B. Liebman, Lawrence F. Katz, and Lisa Sanbonmatsu. 2004. "Moving to Opportunity and Tranquility: Neighborhood Effects on Adult Economic Self-Sufficiency and Health from a Randomized Housing Voucher Experiment." Available at http://www.princeton.edu/ kling/mto/recent.html.

Korenman, Sanders and David Neumark. 1991. "Does Marriage Really Make Men More Productive?" Journal of Human Resources, 26(2): 282-307.

Lewis, Dan A., Amy Bush Stevens, Kristen Shook Slack, and Bong Joo Lee. 2002. Welfare Reform in Illinois: Is the Moderate Approach Working? Evanston, IL: Institute for Policy Research, Northwestern University.

Lewis, Dan A., Laura B. Amsden, Kristen Shook Slack, and Bong Joo Lee. 2004. The Two Worlds of Welfare Reform in Illinois: Work and Welfare Six Years after Reform. Evanston, IL: Institute for Policy Research, Northwestern University. 
Mead, Lawrence M. 1986. Beyond Entitlement: The Social Obligations of Citizenship. New York: Free Press.

Moffitt, Robert. 1992. "Incentive Effects of the U.S. Welfare System: A Review." Journal of Economic Literature 30(1): 1-61.

Murray, Charles. 1984. Losing Ground: American Social Policy 1950 - 1980. New York: Basic Books.

Newcombe, Howard B. 1988. Handbook of Record linkage: Methods for Health and Statistical Studies, Administration, and Business. Oxford: Oxford University Press.

O’Neill, June. 1990. "The Role of Human Capital in Earnings Differences between Black and White Men." Journal of Economic Perspectives 4: 25-46.

Polit, Denise F., Andrew S. London, and John M. Martinez. 2001. The Health of Poor Urban Women: Findings from the Project on Devolution and Urban Change. New York: Manpower Demonstration Research Corporation.

Raudenbush, Steven W. and Anthony S. Bryk. 2002. Hierarchical Linear Models: Applications and Data Analysis Methods. Newbury Park: Sage.

Rolston. Howard. 1999. Effects of Changes to the Welfare System. Testimony before the Subcommittee on Human Resources of the House Committee on Ways and Means. http://www.house.gov.ways_means/humres/106cong/5-27-99/5-27rols.htm.

Smith, James and Finis R. Welch. 1989. "Black Economic Progress after Mydral.” Journal of Economic Literature June: 519-64.

USDHHS. 2000. http://www.acf.dhhs.gov/news/stats/caseload.htm.

USDHHS. 2003a. http://www.hhs.gov/news/press/2003pres/20031202.html.

USDHHS. 2003b. http://aspe.hhs.gov/hsp/TANF-IL-emp03/apc.htm.

Zedlewski, Sheila. R. 1999. Work Activity and Obstacles to Work Among TANF Recipients. Washington, D.C.: The Urban Institute. 


\section{Appendix: List of Independent Variables}

\section{Indices of Human Capital}

Education. Coded as "1" when the respondent has a high school degree or GED and " 0 " otherwise.

Job Skills. Job skills are measured using Holzer's (1996) scale of tasks required in most entry level jobs. Coded as " 1 " if an individual has completed at least 4 of 7 tasks on the job and " 0 " otherwise.

Physical Health. Coded at "1" if an individual reports being in fair or poor health or has a chronic health condition and "0" otherwise.

\section{Non-Wage Income}

Child Support. Coded as "1" if the respondent receives formal child support payments through the State, money for child expenses, or in-kind support for at least one child at least every other month and " 0 " otherwise.

Financial Support. Coded as "1" if a marital or nonmarital partner contributes to family living expenses "pretty regularly" or "all the time" and " 0 " otherwise.

Housing Subsidy. Those who pay a lower rent because the government pays part of the cost of rent are considered to have a housing subsidy (coded as " 1 " for those individuals and "0" otherwise). This includes residence in a public housing project as well as rent voucher programs, such as Section 8.

\section{Neighborhood Characteristics}

All data on neighborhood characteristics are taken from the 2000 Census. All variables are continuous.

Average Income. This represents the average income in the Census tract in which the respondent lives at each wave of the survey. For multivariate analyses, this is coded " 1 " if average income in the Census tract is $>\$ 40,000$ and " 0 " otherwise.

Percent Unemployment. This variable represents the percent unemployment in the Census tract in which the respondent lives at each wave of the survey.

\section{Demographic Characteristics}

Race/Ethnicity. We created dummies for Hispanic, white, and other race. African Americans were the comparison group.

Age. This is a continuous variable measured at each wave of the survey.

Marital Status. Coded "1" for individuals who are married or cohabitate and " 0 " otherwise.

Presence of a Young Child. Coded as "1" for caregivers who have at least one child less than three years of age and " 0 " otherwise.

\section{Controls}

Time on Welfare. This is a continuous variable that represents the total months the respondent received AFDC/TANF between February 1989 and the sampling period, Fall 1998. We use administrative data from the Illinois Department of Human Services to measure welfare history. We constructed a dummy which took the value of " 1 " if the person were on welfare for nine or more years and " 0 " otherwise. 
Table 1. Arithmetic Means and Proportions for Selected Variables of Interest

\begin{tabular}{|c|c|c|c|c|}
\hline Variables of Interest & Wave 1 & Wave 2 & Wave 3 & Wave 4 \\
\hline Number of Months in Labor Force & 5.9 & 6.0 & 6.1 & 5.5 \\
\hline Number of Months Could Have Workec & 12.0 & 14.2 & 12.1 & 12.0 \\
\hline Earnings & 4,867 & 5,751 & 6,462 & 6,748 \\
\hline \multicolumn{5}{|l|}{ Human Capital } \\
\hline High School Degree & $58.9 \%$ & $71.0 \%$ & $71.5 \%$ & $72.6 \%$ \\
\hline Job Skills & $70.7 \%$ & $71.6 \%$ & $72.6 \%$ & $72.9 \%$ \\
\hline Poor Health & $31.9 \%$ & $25.3 \%$ & $22.4 \%$ & $24.1 \%$ \\
\hline \multicolumn{5}{|l|}{ Non-Wage Income } \\
\hline Child Support & $48.9 \%$ & $55.0 \%$ & $57.0 \%$ & $58.5 \%$ \\
\hline Financial Support & $19.9 \%$ & $26.8 \%$ & $27.9 \%$ & $30.5 \%$ \\
\hline Housing Subsidy & $25.5 \%$ & $22.0 \%$ & $25.0 \%$ & $30.3 \%$ \\
\hline \multicolumn{5}{|l|}{ Neighborhood Characteristics } \\
\hline Average Income & 29,593 & 30,980 & 30,590 & 30,650 \\
\hline Percent Poverty & $30.1 \%$ & $27.9 \%$ & $28.0 \%$ & $27.9 \%$ \\
\hline Percent Unemployment & $18.0 \%$ & $16.9 \%$ & $16.9 \%$ & $16.7 \%$ \\
\hline \multicolumn{5}{|l|}{ Demographic Characterictics } \\
\hline Black & $78.0 \%$ & $78.2 \%$ & $79.1 \%$ & $78.2 \%$ \\
\hline Hispanic & $11.8 \%$ & $12.7 \%$ & $12.2 \%$ & $12.5 \%$ \\
\hline White & $8.2 \%$ & $7.4 \%$ & $7.1 \%$ & $7.4 \%$ \\
\hline Age & 31.7 & 32.6 & 33.7 & 34.6 \\
\hline Married & $16.0 \%$ & $18.7 \%$ & $18.8 \%$ & $20.8 \%$ \\
\hline Number of Kids & 2.5 & 2.6 & 2.6 & 2.7 \\
\hline \multicolumn{5}{|l|}{ Controls } \\
\hline Time on Welfare (Months) & 77.1 & 78.0 & 79.0 & 78.1 \\
\hline Informal Work & $29.2 \%$ & $26.3 \%$ & $21.0 \%$ & $21.6 \%$ \\
\hline $\mathrm{N}$ & 1363 & 1183 & 1072 & 967 \\
\hline
\end{tabular}


Table 2. Work Status and Welfare Use: Percentages.

\begin{tabular}{lcccc}
\hline & Wave 1 & Wave 2 & Wave 3 & Wave 4 \\
\hline Work only & $29.80 \%$ & $42.50 \%$ & $44.70 \%$ & $46.20 \%$ \\
Work and Welfare & $20.60 \%$ & $10.40 \%$ & $4.20 \%$ & $1.50 \%$ \\
Welfare only & $31.50 \%$ & $20.40 \%$ & $14.30 \%$ & $9.10 \%$ \\
No Work/ No Welfare & $18.10 \%$ & $26.60 \%$ & $36.80 \%$ & $43.00 \%$ \\
\hline $\mathrm{N}$ & 1363 & 1183 & 1072 & 967 \\
\hline
\end{tabular}

Note: Percentages do not always sum to $100 \%$ due to rounding. 
Table 3. Regression Estimates Using Tobit: Labor Force Participation

\begin{tabular}{|c|c|c|c|c|c|c|c|c|}
\hline \multirow{3}{*}{$\begin{array}{l}\text { Independent Variables } \\
\text { Human Capital }\end{array}$} & \multicolumn{6}{|c|}{ Proportion of Months in the Labor Force } & \multirow{2}{*}{\multicolumn{2}{|c|}{ Wave 4}} \\
\hline & \multicolumn{2}{|c|}{ Wave 1} & \multicolumn{2}{|c|}{ Wave 2} & \multicolumn{2}{|c|}{ Wave 3} & & \\
\hline & Estimate & SE & Estimate & SE & Estimate & SE & Estimate & SE \\
\hline High School Degree & 0.082 & 0.032 & 0.117 & 0.039 & 0.227 & 0.041 & 0.194 & 0.04 \\
\hline Job Skills & 0.089 & 0.034 & -0.030 & 0.039 & 0.038 & 0.041 & 0.085 & 0.04 \\
\hline Poor Health & -0.112 & 0.033 & -0.159 & 0.042 & -0.012 & 0.045 & -0.312 & 0.05 \\
\hline \multicolumn{9}{|l|}{ Non-Wage Income } \\
\hline Child Support & 0.016 & 0.031 & -0.070 & 0.035 & -0.002 & 0.037 & 0.017 & 0.04 \\
\hline Financial Support & 0.040 & 0.041 & -0.030 & 0.044 & 0.116 & 0.047 & -0.047 & 0.05 \\
\hline Housing Subsidy & 0.105 & 0.037 & 0.154 & 0.043 & 0.110 & 0.045 & 0.172 & 0.05 \\
\hline \multicolumn{9}{|l|}{ Neighborhood Characteristics } \\
\hline Average Income $>\$ 40,000$ & 0.033 & 0.040 & 0.015 & 0.047 & 0.027 & 0.050 & 0.038 & 0.06 \\
\hline Percent Unemployment & -0.385 & 0.173 & -0.438 & 0.224 & 0.155 & 0.229 & 0.516 & 0.28 \\
\hline \multicolumn{9}{|l|}{ Demographic Characteristics } \\
\hline White & -0.036 & 0.048 & -0.007 & 0.071 & -0.009 & 0.074 & 0.042 & 0.08 \\
\hline Hispanic & 0.152 & 0.060 & -0.029 & 0.054 & 0.100 & 0.058 & 0.026 & 0.06 \\
\hline Other & -0.131 & 0.154 & -0.573 & 0.167 & -0.386 & 0.160 & -0.986 & 0.23 \\
\hline Age: Linear Term & 0.050 & 0.014 & 0.028 & 0.016 & 0.034 & 0.018 & 0.046 & 0.02 \\
\hline Age: Quadratic Term & -0.0007 & 0.0002 & -0.0005 & 0.0002 & -0.0006 & 0.0002 & -0.0007 & 0.00 \\
\hline Married & -0.079 & 0.046 & 0.113 & 0.050 & -0.171 & 0.056 & 0.045 & 0.02 \\
\hline One Child $<3$ Years Old & -0.024 & 0.041 & -0.182 & 0.039 & -0.181 & 0.043 & -0.126 & 0.04 \\
\hline \multicolumn{9}{|l|}{ Controls } \\
\hline Nine or More Years on Welfare & 0.007 & 0.035 & -0.037 & 0.041 & -0.037 & 0.041 & -0.042 & 0.05 \\
\hline Family Hardship & -0.051 & 0.030 & -0.118 & 0.034 & -0.118 & 0.035 & -0.004 & 0.04 \\
\hline Housing Expenses & 0.0005 & 0.0001 & 0.0006 & 0.0001 & 0.0005 & 0.0001 & 0.0007 & 0.00 \\
\hline Region: Cook County Vs DownSta & -0.245 & 0.052 & -0.107 & 0.061 & -0.258 & 0.063 & -0.348 & 0.07 \\
\hline
\end{tabular}


Table 4. Regression Estimates Using Tobit: Earnings

\begin{tabular}{|c|c|c|c|c|c|c|c|c|}
\hline \multirow{3}{*}{$\begin{array}{l}\text { Independent Variables } \\
\text { Human Capital }\end{array}$} & \multicolumn{6}{|c|}{ Log Earnings } & \multirow{2}{*}{\multicolumn{2}{|c|}{ Wave 4}} \\
\hline & \multicolumn{2}{|c|}{ Wave 1} & \multicolumn{2}{|c|}{ Wave 2} & \multicolumn{2}{|c|}{ Wave 3} & & \\
\hline & Estimate & SE & Estimate & SE & Estimate & SE & Estimate & SE \\
\hline High School Degree & 1.375 & 0.369 & 0.316 & 0.398 & 1.360 & 0.487 & 1.888 & 0.56 \\
\hline Job Skills & 0.255 & 0.396 & 0.899 & 0.401 & 0.125 & 0.488 & 1.218 & 0.56 \\
\hline Poor Health & -1.230 & 0.390 & -2.040 & 0.441 & -1.179 & 0.542 & -1.499 & 0.62 \\
\hline \multicolumn{9}{|l|}{ Neighborhood Characteristics } \\
\hline Average Income $>\$ 40,000$ & 1.677 & 0.474 & 1.477 & 0.487 & 0.462 & 0.589 & 0.111 & $0.6 \varepsilon$ \\
\hline Percent Unemployment & 0.377 & 1.984 & -2.125 & 2.290 & -3.759 & 2.741 & 0.423 & 3.25 \\
\hline \multicolumn{9}{|l|}{ Demographic Characteristics } \\
\hline White & 0.285 & 0.685 & -0.990 & 0.741 & -1.547 & 0.862 & -0.205 & 0.95 \\
\hline Hispanic & 0.946 & 0.567 & -0.035 & 0.554 & -0.030 & 0.681 & 0.711 & $0.7 \varepsilon$ \\
\hline Other & -13.445 & 2.613 & -9.817 & 2.093 & -5.069 & 2.008 & -10.527 & 2.62 \\
\hline Age: Linear Term & 0.447 & 0.167 & 0.321 & 0.166 & 0.352 & 0.208 & 0.120 & 0.26 \\
\hline Age: Quadratic Term & -0.007 & 0.002 & -0.005 & 0.002 & -0.006 & 0.003 & -0.003 & 0.00 \\
\hline Married & -0.039 & 0.485 & -0.616 & 0.455 & -0.216 & 0.544 & -0.672 & 0.62 \\
\hline One Child $<3$ Years Old & -0.928 & 0.472 & -1.962 & 0.391 & -1.169 & 0.505 & -0.753 & 0.5 \\
\hline \multicolumn{9}{|l|}{ Controls } \\
\hline Nine or More Years on Welfare & -0.778 & 0.406 & -0.554 & 0.419 & -0.574 & 0.490 & 0.936 & $0.5 \varepsilon$ \\
\hline Family Hardship & -0.455 & 0.358 & -1.043 & 0.353 & -0.884 & 0.422 & -0.636 & $0.4 \varsigma$ \\
\hline Housing Expenses & 0.002 & 0.001 & 0.002 & 0.001 & 0.004 & 0.001 & 0.004 & 0.00 \\
\hline Informal Work & -1.130 & 0.391 & -1.217 & 0.410 & -2.662 & 0.544 & -3.014 & 0.63 \\
\hline Region: Cook County Vs DownSta & -0.604 & 0.613 & -0.910 & 0.633 & -1.030 & 0.759 & -1.506 & 0.86 \\
\hline
\end{tabular}


Table 5. Two-Level Estimates: Longitudinal Analysis

\begin{tabular}{|c|c|c|c|c|}
\hline \multirow[b]{2}{*}{ Independent Variables at Wave 1} & \multicolumn{4}{|c|}{ Temporal Change:Waves 1 to 4} \\
\hline & $\begin{array}{l}\text { Labor Force } \\
\text { Participation }\end{array}$ & & Earnings & \\
\hline & Estimate & SE & Estimate & SE \\
\hline Average Temporal Change from Wave 1 to Wavı & 0.022 & 0.006 & -0.047 & 0.049 \\
\hline \multicolumn{5}{|l|}{ Human Capital } \\
\hline High School Degree & 0.048 & 0.013 & 0.288 & 0.123 \\
\hline Job Skills & 0.003 & 0.014 & 0.175 & 0.127 \\
\hline Poor Health & -0.026 & 0.013 & -0.193 & 0.132 \\
\hline \multicolumn{5}{|l|}{ Non-Wage Income } \\
\hline Child Support & 0.017 & 0.012 & & \\
\hline Financial Support & 0.003 & 0.015 & & \\
\hline Housing Subsidy & 0.030 & 0.015 & & \\
\hline \multicolumn{5}{|l|}{ Neighborhood Characteristics } \\
\hline Average Income $>\$ 40,000$ & 0.015 & 0.016 & 0.091 & 0.163 \\
\hline Percent Unemployment & 0.105 & 0.064 & 0.800 & 0.596 \\
\hline \multicolumn{5}{|l|}{ Demographic Characteristics } \\
\hline White & 0.002 & 0.021 & -0.093 & 0.230 \\
\hline Hispanic & 0.026 & 0.022 & 0.193 & 0.179 \\
\hline Other & -0.072 & 0.072 & -0.052 & 0.566 \\
\hline Age: Linear Term & 0.006 & 0.005 & -0.019 & 0.047 \\
\hline Age: Quadratic Term & -0.0001 & 0.00008 & 0.0001 & 0.0007 \\
\hline Married & -0.019 & 0.017 & -0.043 & 0.147 \\
\hline One Child $<3$ Years Old & 0.001 & 0.016 & -0.084 & 0.142 \\
\hline \multicolumn{5}{|l|}{ Controls } \\
\hline Nine or More Years on Welfare & -0.016 & 0.014 & 0.105 & 0.129 \\
\hline Family Hardship & -0.011 & 0.012 & -0.172 & 0.111 \\
\hline Housing Expenses & 0.0001 & 0.00004 & 0.0006 & 0.0003 \\
\hline Informal Work & & & -0.091 & 0.119 \\
\hline Region: Cook County Vs DownState & -0.062 & 0.011 & -0.213 & 0.113 \\
\hline
\end{tabular}

